\title{
An investigation of the choice of governance modes in Chinese family firms ${ }^{* 1}$
}

\author{
Jiancai $P i^{2}$
}

\begin{abstract}
This paper aims to investigate the choice of governance modes in Chinese family firms. For that purpose, we build a principal-agent model to conduct our analyses. There are two modes of governance that the owner of the family firm can choose from, either the relational governance or the professional governance. The choice of governance modes is embodied in managerial compensation under different contractual arrangements. Our theoretical analyses show that under some conditions it is optimal for the owner to choose the relational governance, while under other conditions it is optimal for the owner to adopt the professional governance. That is to say, the choice of governance modes is condition-dependent.
\end{abstract}

Key words: relational governance, professional governance, Chinese family firm, moral hazard

JEL classification: L20, M21, J33

\section{Introduction}

Family-owned firms are more common in emerging markets (Milana and Wang, 2013). With the great development of Chinese economy, the professionalization of family firms becomes a major research concern in China. Many Chinese family firms make their efforts to adopt suitable governance modes by trial and error in order to

\footnotetext{
* Received: 08-07-2015; accepted: 15-12-2015

1 This paper is supported by the Program for New Century Excellent Talents in University and the Fundamental Research Funds for the Central Universities. The author would like to thank the editor and two anonymous reviewers for their sincere help and suggestive comments on improving this paper.

2 Full Professor of Economics, Department of Economics, School of Business, Nanjing University, 22 Hankou Road, Nanjing 210093, China. Scientific affiliation: organizational economics, development economics.Phone: +862583621121(O).E-mail:pi2008@nju.edu. cn; jiancaipi@hotmail.com. Website: http://nubs.nju.edu.cn/en/faculty.php/160; http://nubs. nju.edu.cn/faculty.php/160.
} 
accommodate themselves to the changing domestic and international situations. At the primary stage, Chinese family firms rely heavily on the relational governance, which is embraced with emotions, obligations, and reciprocities between owners and managers. Relation (or guanxi in Chinese language) plays an important role in making the relational governance work well because relation itself can act as a tool to reduce the agents' moral hazard and to promote the principals' clan reputation.

However, relational managers have innate drawbacks because their managerial abilities are oftentimes limited and insufficient. Although relational managers can do their work excellently under some circumstances, they have too many difficulties to cope with complex situations due to the fact that their capacities fall short of requirements. Thus, family firms often become involved in predicaments which impose restrictions on their further growth. According to Cheng (2014, p.157), "[A]lthough family firms operate in a wide range of industries, most are in industries that have enjoyed growth in recent years, such as petro-chemical, electronic, iron/steel mills, machinery, pharmaceutical, telecommunication, and real estate." When Chinese family firms develop to a certain stage, owners are often forced to consider the possibility of the introduction of professional managers.

Professional managers are greatly different from relational counterparts in two respects. Firstly, they are not tied up to the mutual relation with owners, and they often behave selfishly and do not care for the owners' utility functions at all. Secondly, they are usually more able than relational counterparts in that they have received professional trainings. Owners have to make a tradeoff in order to maximize their utility functions. On the one hand, owners could adopt the relational governance, which have an advantage in in-group effects (or zijiren xiaoying in Chinese language). Some scholars also term it as "family involvement in management" (see e.g., Kim and Gao, 2013; Dou et al., 2014; Liang et al., 2014). On the other hand, the owners could adopt the professional governance, which implies that the hired managers are more able but with higher degree of moral hazard.

On the basis of important facts and empirical observations concerning Chinese family firms, this paper hypothesizes that under some conditions it is optimal for the owner to choose the relational governance, while under other conditions it is optimal for the owner to adopt the professional governance. That is, the choice of governance modes hinges upon the specific conditions. We will use the principal-agent model to prove our main hypotheses. This paper offers an applied theoretical investigation, not an empirical investigation, of Chinese family firms.

The rest of the paper is organized as follows. Section 2 provides literature review on the related works in this field. In Section 3, we conduct a theoretical analysis of the relational governance and the professional governance and compare the outcomes derived from the two different governance modes. In Section 4, we further discuss the main results in order to comprehend them more visually. Some concluding remarks are made in Section 5. 


\section{Literature review}

The choice of governance modes is embodied in managerial compensation under different contractual arrangements. According to Bebchuk and Weisbach (2010), there are two strands of literature which are related to our paper. The first strand of literature focuses on the optimal contracting (e. g., Holmstrom, 1979), and the second strand of literature concentrates on the managerial power (e. g., Bebchuk and Fried, 2003). On the basis of these two strands of literature, when the owner hires the manager to operate the family firm, he faces serious opportunistic problems on the part of the manager. In order to solve such problems, the owner has to find suitable institutional arrangements.

There is a lot of literature exploring the related issues. Pi (2011b) highlighted the role of relational incentive mechanism in which the owner can pick out the optimal managerial compensation contract in order to better incentivize the relation-based manager. Zhang and Ma (2009) emphasized the importance of the relative strength of impetus factors (e.g., market imperatives and firm size) and impediment factors (e.g., cultural tradition and familism) in governance choices. Zhou et al. (2013) stressed the role of control-enhancing mechanisms, and their empirical analysis found that relational managers in general outperform professional managers. Kim and Gao (2013) showed that a firm's family-longevity goals play an important role in determining business performance of different governance modes. Zhou et al. (2015) found that family ownership concentration and investor protection could be substitutable when managerial power remains in the family. Amit et al. (2015) showed institutional efficiency has an effect on the prevalence and performance of different governance modes.

This paper tries to answer the question of what determines the adoption of the relational governance or the professional governance. According to Zhang and Ma (2009, p. 120), "Addressing such a research question is likely to help us better understand the professionalization of family business in a setting different from the hitherto dominant perspective and context in the literature, and hopefully make a theoretical contribution to extend and enrich the mainstream literature of concern." The Nobel Prize laureate Ronald Coase and his collaborator profoundly pointed out that incentives and relation are indispensible for the successful operation of Chinese family firms (Coase and Wang, 2010). Cai et al. (2013) provided strong evidence supporting that family ties are important in shaping the internal organization of Chinese family firms.

This paper provides a new perspective on the choice of governance modes in Chinese family firms. Specifically, we find some key influence factors which are left aside by the existing literature, and analyze the role of these factors through an improved principal-agent moral hazard framework. We conduct our analysis by using a formal theoretical model, while the existing studies (e.g., Zhang and Ma, 2009; Zhou et 
al., 2013) usually used data to conduct the empirical analysis. Firstly, we use the relational manager's uneasiness cost and degree of altruism, and the owner's clan rent to depict the substantive characteristics of the relational governance. Secondly, we use a parameter related to the professional manager's ability to describe the professional governance. Different governance modes signify different contractual choices, and different contractual choices imply different types of managers hired, and different types of managers hired mean different equilibrium outcomes.

\section{Model of analysis}

\subsection{The basic set-up}

In this section, we follow Laffont and Martimort's (2002) analytical framework and Itoh's (2004) behavioral contract approach. In a principal-agent game, the owner is a principal and the manager is an agent. It is assumed that both the owner and the manager are risk-neutral. If the manager exerts effort level $e \in\{0,1\}$, then the firm's added-value will be $\bar{V}$ with probability $\pi(e)$, and $\underline{V}$ with probability $1-\pi(e)$, where $0 \leq \pi(e) \leq 1$. When the manager exerts no effort, his effort cost is $\Psi_{0}$. When the manager exerts effort, his effort cost is $\Psi_{1}=\Psi>0$. In this paper, $\Psi$ is called the manager's exertion cost. The subscripts 0 and 1 represent $e=0$ and $e=1$, respectively. The following mathematical definitions should be noted, $\pi(1)=\pi_{1}, \pi(0)=\pi_{0}, \Delta \pi=\pi_{1}-\pi_{0}>0, \Delta V=\bar{V}-\underline{V}>0$. In order to make our analysis interesting, throughout the paper we assume that $\Psi \leq \Delta \pi \Delta V$. According to $\Delta \pi=\pi_{1}-\pi_{0}>0$ and $\Delta V=\bar{V}-\underline{V}>0$, we can easily find that $\pi_{1} \overline{\bar{V}}+\left(1-\pi_{1}\right) \underline{V} \geq \Delta \pi \Delta V$. So it is obvious that $\Psi \leq \pi_{1} \bar{V}+\left(1-\pi_{1}\right) \underline{V}$.

There are two modes of governance that the owner of the family firm can choose from, either the relational governance or the professional governance. We suppose that both the relational governance and the professional governance adopt the share-based incentive contract to incentivize the manager. According to $\mathrm{Pi}$ (2011b), the owner of the family firm can choose an efficiency wage contract or a sharebased incentive contract to motivate the manager to work hard, where the efficiency wage contract can be seen as a relatively high-powered incentive arrangement and the share-based incentive contract can be considered as a relatively low-powered incentive arrangement. In this paper, in order to simplify our analyses, we adopt the "relatively low-powered" share-based incentive contract. This simplification is beneficial for us to find out the role of relatively low-powered incentive arrangement which is more widely used in practice and at the same time it is easy for us to obtain explicit solutions.

Firstly, we consider the case of the relational governance. In this case, the owner gets $1-\alpha$ proportion of the firm's added-value and the relational manager obtains 
$\alpha$ proportion, where $0 \leq \alpha \leq 1$. The relational manager has two characteristic marks that are greatly different from the professional counterpart. First, the relational manager's utility function includes both his own income and his concern for the owner's share, and $\lambda$ is used to delineate the relational manager's degree of altruism, where $\lambda>0$. In order to make our analysis interesting, we assume that $\lambda$ is sufficiently small. It is certain that $\lambda$ can also be seen as the relational strength (or guanxi qiangd $u$ in Chinese language). It should be noted that $\lambda$ in the altruistic sense is borrowed from Becker (1976). Second, the relational manager's psychological cost is $\Psi_{0}^{R}$ when he does not exert effort, where $0<\Psi_{0}^{R}<\Psi$. In this paper, $\Psi_{0}^{R}$ can be seen as the relational manager's uneasiness cost. The economic spirit of $\Psi_{0}^{R}$ is borrowed from Pi (2011a, 2011b). Throughout the paper, the superscript $R$ represents the relational governance, and the subscript 0 stands for $e=0$. When the owner adopts the mode of the relational governance, he can obtain some kind of clan rent which comes from his relation management (or guanxi yunzuo in Chinese language) within the whole family (see Dou and Li, 2013). $f$ is used to denote the clan rent, where $f>0$. For example, the owner can arrange his family members in different positions inside the family firm, which can bring praise-based authority to him. Such clan rent is an additional benefit. Here, it should be noted that $f$ is highly stressed by Yang (2009) and other Chinese scholars.

Secondly, we consider the case of the professional governance. Although business professionalization has other feathers (see, e.g., Dekker et al., 2015), we adopt the traditional treatment that there exists a nonfamily manager. In this case, the owner obtains $1-\alpha$ proportion of the firm's added-value and the professional manager obtains $\alpha$ proportion, where $0 \leq \alpha \leq 1$. The professional manager's utility function only includes his own income, and there is no psychological cost at all when the professional manager does not exert effort, i.e., $\Psi_{0}^{P}=0$. Throughout the paper, the superscript $P$ stands for the professional governance. The professional manager has a characteristic mark that is greatly different from the relational one. That is to say, the professional manager is more able than the relational manager (see Burkart et al., 2003). In this paper, we use $s$ to depict the professional manager's higher ability, where $s>1$. It should be noted that $s$ is highlighted by Carney (1998), Yang (2009), Bi (2010), Xie (2011) and others. There are two points that should be noted. Firstly, the role of the professional manager's ability is embodied in changing the firm's added-value from $\bar{V}$ and $\underline{V}$ to $s \bar{V}$ and $s \underline{V}$, respectively. Secondly, the professional manager is disciplined by the managerial labor market to some degree, which can ensure that the average ability of the professional manager is higher than that of the relational manager.

It should be noted that $\Psi_{0}^{P}=0<\Psi_{0}^{R}$ actually implies that "the family manager works harder than the professional manager because her interests are more aligned with those of the firm head" (see Cai et al., 2013).

Here, we can use Figure 1 to describe the above-mentioned modes of governance. 
Figure 1: Governance modes in Chinese family firms

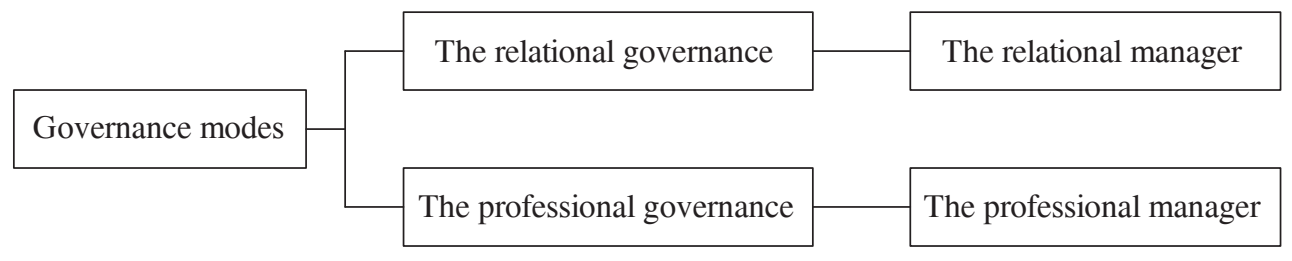

Source: Author's concept

The timing of the principal-agent game is as follows.

(i) At $\mathrm{t}=1$, the owner decides to choose the relational governance or the professional governance.

(ii) At $t=2$, a relational manager or a professional manager is hired which depends on the owner's choice of governance modes.

(iii) At $t=3$, the hired manager chooses an effort, which is either 1 or 0 .

(iv) At $\mathrm{t}=4$, the firm's added-value is realized.

(v) At $t=5$, the signed contract is enforced.

\subsection{Relational governance}

When it is under the relational governance, the principal will maximize his objective function subject to the relational manager's relevant constraints.

In this case, the principal programming problem will be:

$$
\begin{aligned}
& \max _{\alpha}(1-\alpha)\left[\pi_{1} \bar{V}+\left(1-\pi_{1}\right) \underline{V}\right]+f \\
& \text { s.t. } \alpha\left[\pi_{1} \bar{V}+\left(1-\pi_{1}\right) \underline{V}\right]-\Psi+\lambda(1-\alpha)\left[\pi_{1} \bar{V}+\left(1-\pi_{1}\right) \underline{V}\right] \\
& \geq \alpha\left[\pi_{0} \bar{V}+\left(1-\pi_{0}\right) \underline{V}\right]-\Psi_{0}^{R}+\lambda(1-\alpha)\left[\pi_{0} \bar{V}+\left(1-\pi_{0}\right) \underline{V}\right] \\
& \alpha\left[\pi_{1} \bar{V}+\left(1-\pi_{1}\right) \underline{V}\right]-\Psi+\lambda(1-\alpha)\left[\pi_{1} \bar{V}+\left(1-\pi_{1}\right) \underline{V}\right] \geq 0 \\
& \alpha\left[\pi_{0} \bar{V}+\left(1-\pi_{0}\right) \underline{V}\right]-\Psi_{0}^{R}+\lambda(1-\alpha)\left[\pi_{0} \bar{V}+\left(1-\pi_{0}\right) \underline{V}\right] \geq 0
\end{aligned}
$$

(1) and (2a, b) are the relational manager's incentive compatibility and participation constraints, respectively. 
Throughout this paper, the incentive compatibility constraint can ensure that the agent exerts high effort, and the participation constraint can ensure that the agent joins the activity.

It is obvious that $\frac{\Psi-\Psi_{0}^{R}}{\Delta \pi \Delta V} \geq \frac{\Psi}{\pi_{1} \bar{V}+\left(1-\pi_{1}\right) \underline{V}}$ is equivalent to

$\frac{\Psi}{\pi_{1} \bar{V}+\left(1-\pi_{1}\right) \underline{V}} \geq \frac{\Psi_{0}^{R}}{\pi_{0} \bar{V}+\left(1-\pi_{0}\right) \underline{V}}$, and that $\frac{\Psi-\Psi_{0}^{R}}{\Delta \pi \Delta V}<\frac{\Psi}{\pi_{1} \bar{V}+\left(1-\pi_{1}\right) \underline{V}}$ is equivalent to $\frac{\Psi}{\pi_{1} \bar{V}+\left(1-\pi_{1}\right) \underline{V}}<\frac{\Psi_{0}^{R}}{\pi_{0} \bar{V}+\left(1-\pi_{0}\right) \underline{V}}$.

Solving this programming problem, we obtain:

If $\Psi \geq \frac{\Psi_{0}^{R}\left[\pi_{1} \bar{V}+\left(1-\pi_{1}\right) \underline{V}\right]}{\left[\pi_{1} \bar{V}+\left(1-\pi_{1}\right) \underline{V}\right]-\Delta \pi \Delta V}$, then $\alpha^{R^{*}}=\frac{\Psi-\Psi_{0}^{R}-\lambda \Delta \pi \Delta V}{(1-\lambda) \Delta \pi \Delta V}$

If $\Psi<\frac{\Psi_{0}^{R}\left[\pi_{1} \bar{V}+\left(1-\pi_{1}\right) \underline{V}\right]}{\left[\pi_{1} \bar{V}+\left(1-\pi_{1}\right) \underline{V}\right]-\Delta \pi \Delta V}$, then $\alpha^{R^{*}}=\frac{\Psi-\lambda\left[\pi_{1} \bar{V}+\left(1-\pi_{1}\right) \underline{V}\right]}{(1-\lambda)\left[\pi_{1} \bar{V}+\left(1-\pi_{1}\right) \underline{V}\right]}$

If $\Psi \geq \frac{\Psi_{0}^{R}\left[\pi_{1} \bar{V}+\left(1-\pi_{1}\right) \underline{V}\right]}{\left[\pi_{1} \bar{V}+\left(1-\pi_{1}\right) \underline{V}\right]-\Delta \pi \Delta V}$, then the owner's equilibrium utility will be:

$$
U_{O}^{R^{*}}=\frac{\left[(1+\lambda) \Delta \pi \Delta V-\left(\Psi-\Psi_{0}^{R}\right)\right]\left[\pi_{1} \bar{V}+\left(1-\pi_{1}\right) \underline{V}\right]}{\Delta \pi \Delta V}+f
$$

If $\Psi<\frac{\Psi_{0}^{R}\left[\pi_{1} \bar{V}+\left(1-\pi_{1}\right) \underline{V}\right]}{\left[\pi_{1} \bar{V}+\left(1-\pi_{1}\right) \underline{V}\right]-\Delta \pi \Delta V}$, then the owner's equilibrium utility will be:

$$
U_{O}^{R^{*}}=(1+\lambda)\left[\pi_{1} \bar{V}+\left(1-\pi_{1}\right) \underline{V}\right]-\Psi+f
$$

The subscript $O$ stands for the owner. The superscript $R^{*}$ stands for second-best state under the relational governance. $\alpha R^{*}$ is the relational manager's equilibrium proportion.

Through comparative statics, we can obtain Proposition 1. 
Proposition 1: When it is under the relational governance, $\frac{\partial U_{O}^{R^{*}}}{\partial \lambda}>0, \frac{\partial U_{O}^{R^{*}}}{\partial f}>0$, $\frac{\partial U_{O}^{R^{*}}}{\partial \Psi_{0}^{R}} \geq 0$, irrespective of whether $\Psi \geq \frac{\Psi_{0}^{R}\left[\pi_{1} \bar{V}+\left(1-\pi_{1}\right) \underline{V}\right]}{\left[\pi_{1} \bar{V}+\left(1-\pi_{1}\right) \underline{V}\right]-\Delta \pi \Delta V}$ or $\Psi<\frac{\Psi_{0}^{R}\left[\pi_{1} \bar{V}+\left(1-\pi_{1}\right) \underline{V}\right]}{\left[\pi_{1} \bar{V}+\left(1-\pi_{1}\right) \underline{V}\right]-\Delta \pi \Delta V}$.

Proof: When $\Psi \geq \frac{\Psi_{0}^{R}\left[\pi_{1} \bar{V}+\left(1-\pi_{1}\right) \underline{V}\right]}{\left[\pi_{1} \bar{V}+\left(1-\pi_{1}\right) \underline{V}\right]-\Delta \pi \Delta V}$, then from (5), we obtain:

$\frac{\partial U_{O}^{R^{*}}}{\partial \lambda}=\pi_{1} \bar{V}+\left(1-\pi_{1}\right) \underline{V}>0, \frac{\partial U_{O}^{R^{*}}}{\partial f}=1>0, \frac{\partial U_{O}^{R^{*}}}{\partial \Psi_{0}^{R}}=\frac{\pi_{1} \bar{V}+\left(1-\pi_{1}\right) \underline{V}}{\Delta \pi \Delta V} \geq 0$.

When $\Psi<\frac{\Psi_{0}^{R}\left[\pi_{1} \bar{V}+\left(1-\pi_{1}\right) \underline{V}\right]}{\left[\pi_{1} \bar{V}+\left(1-\pi_{1}\right) \underline{V}\right]-\Delta \pi \Delta V}$, then from (6), we obtain:

$\frac{\partial U_{O}^{R^{*}}}{\partial \lambda}=\pi_{1} \bar{V}+\left(1-\pi_{1}\right) \underline{V}>0, \frac{\partial U_{O}^{R^{*}}}{\partial f}=1>0, \frac{\partial U_{O}^{P^{*}}}{\partial \Psi_{0}^{R}}=0$.

Proposition 1 implies that the owner's equilibrium utility is strictly increasing in the relational manager's degree of altruism and the owner's clan rent, and at the same time weakly increasing in the manager's uneasiness cost.

\subsection{Professional governance}

Similarly, when it is under the professional governance, the principal will maximize his objective function subject to the professional manager's relevant constraints.

In this situation, the principal's programming problem will be:

$$
\begin{aligned}
& \max _{\alpha}(1-\alpha)\left[\pi_{1} s \bar{V}+\left(1-\pi_{1}\right) s \underline{V}\right] \\
& \text { s.t. } \alpha\left[\pi_{1} s \bar{V}+\left(1-\pi_{1}\right) s \underline{V}\right]-\Psi \geq \alpha\left[\pi_{0} s \bar{V}+\left(1-\pi_{0}\right) s \underline{V}\right] \\
& \alpha\left[\pi_{1} s \bar{V}+\left(1-\pi_{1}\right) s \underline{V}\right]-\Psi \geq 0
\end{aligned}
$$


(7) and (8) are the professional manager's incentive compatibility and participation constraints, respectively. In fact, there are three constraints that should be considered. Because the professional manager's participation constraint when he exerts no effort $\left(\alpha\left(\pi_{0} \bar{V}+\left(1-\pi_{0}\right) \underline{V}\right) \geq 0\right)$ is always satisfied, it can be neglected during the course of analyses.

Solving this programming problem, we obtain:

$$
\alpha^{P^{*}}=\frac{\Psi}{s \Delta \pi \Delta V}
$$

The owner's equilibrium utility will be:

$$
U_{O}^{P^{*}}=\frac{(s \Delta \pi \Delta V-\Psi)\left[\pi_{1} \bar{V}+\left(1-\pi_{1}\right) \underline{V}\right]}{\Delta \pi \Delta V}
$$

The superscript $P^{*}$ stands for second-best state under the professional governance. $\alpha^{P^{*}}$ is the professional manager's equilibrium proportion.

Through comparative statics, we can obtain Proposition 2.

Proposition 2: When it is under the professional governance, $\frac{\partial U_{O}^{P^{*}}}{\partial s}>0$.

Proof: From (10), we obtain: $\frac{\partial U_{O}^{P *}}{\partial s}=s\left[\pi_{1} \bar{V}+\left(1-\pi_{1}\right) \underline{V}\right]>0$.

Proposition 2 implies that under the professional governance the owner's equilibrium utility is strictly increasing in the professional manager's ability.

\subsection{A comparative analysis}

In this subsection, we will conduct a comparative analysis between the outcomes under the relational governance and the professional governance.

The owner's tradeoff can be described by Figure 2, which shows that the owner needs to make a comparison between the benefits of the relational governance and the benefit of the professional governance. The owner's choice depends on which governance mode brings more equilibrium utility to him. 
Figure 2: The owner's tradeoff between different governance modes

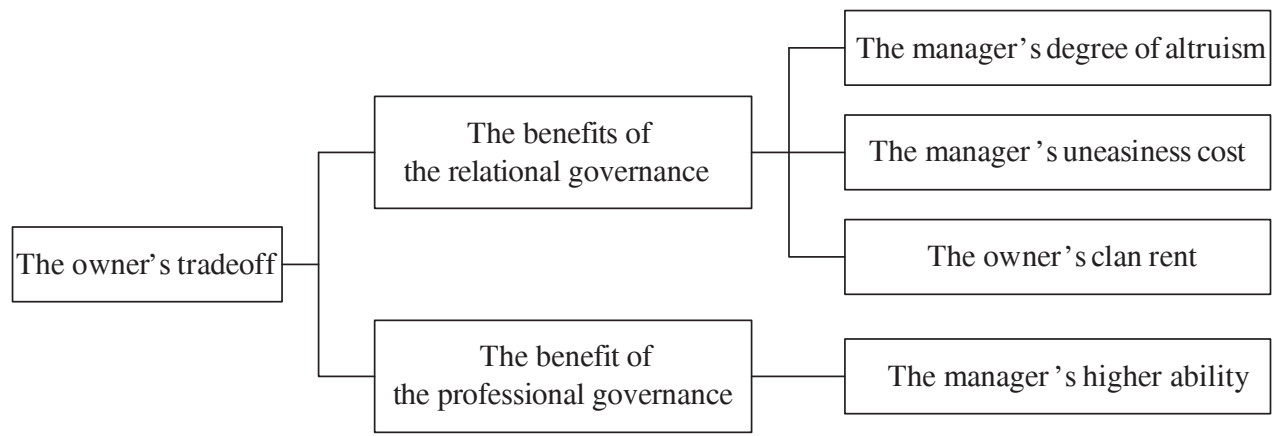

Source: Author's concept

By comparison, it is easy for us to obtain the following two propositions. These two propositions are the main results of this paper, which constitute our main contributions.

Proposition 3: When $\Psi \geq \frac{\Psi_{0}^{R}\left[\pi_{1} \bar{V}+\left(1-\pi_{1}\right) \underline{V}\right]}{\left[\pi_{1} \bar{V}+\left(1-\pi_{1}\right) \underline{V}\right]-\Delta \pi \Delta V}$, if

$s \geq 1+\lambda+\frac{\Psi_{0}^{R}}{\Delta \pi \Delta V}+\frac{f}{\pi_{1} \bar{V}+\left(1-\pi_{1}\right) \underline{V}}$, then it is optimal for the owner to choose the professional governance; if $s<1+\lambda+\frac{\Psi_{0}^{R}}{\Delta \pi \Delta V}+\frac{f}{\pi_{1} \bar{V}+\left(1-\pi_{1}\right) \underline{V}}$, then it is optimal for the owner to choose the relational governance.

Proof: When $\Psi \geq \frac{\Psi_{0}^{R}\left[\pi_{1} \bar{V}+\left(1-\pi_{1}\right) \underline{V}\right]}{\left[\pi_{1} \bar{V}+\left(1-\pi_{1}\right) \underline{V}\right]-\Delta \pi \Delta V}$, if $s \geq 1+\lambda+\frac{\Psi_{0}^{R}}{\Delta \pi \Delta V}+\frac{f}{\pi_{1} \bar{V}+\left(1-\pi_{1}\right) \underline{V}}$, then from (5) and (10), we obtain: $U_{O}^{R^{*}}-U_{O}^{P^{*}} \leq 0$.

When $\Psi \geq \frac{\Psi_{0}^{R}\left[\pi_{1} \bar{V}+\left(1-\pi_{1}\right) \underline{V}\right]}{\left[\pi_{1} \bar{V}+\left(1-\pi_{1}\right) \underline{V}\right]-\Delta \pi \Delta V}$, if $s<1+\lambda+\frac{\Psi_{0}^{R}}{\Delta \pi \Delta V}+\frac{f}{\pi_{1} \bar{V}+\left(1-\pi_{1}\right) \underline{V}}$, then from (5) and (10), we obtain: $U_{O}^{R^{*}}-U_{O}^{P^{*}}>0$.

From Proposition 3, we know that when the exertion cost is sufficiently large relative to the uneasiness cost, if the professional manager's ability is big enough relative to the relational manager's degree of altruism and the owner's clan rent, then the owner tends to choose the professional governance; however, if the professional manager's ability is small enough relative to the relational manager's 
degree of altruism and the owner's clan rent, then the owner tends to choose the relational governance.

Proposition 4: When $\Psi<\frac{\Psi_{0}^{R}\left[\pi_{1} \bar{V}+\left(1-\pi_{1}\right) \underline{V}\right]}{\left[\pi_{1} \bar{V}+\left(1-\pi_{1}\right) \underline{V}\right]-\Delta \pi \Delta V}$, if

$s \geq 1+\lambda+\frac{\Psi\left[\pi_{1} \bar{V}+\left(1-\pi_{1}\right) \underline{V}-\Delta \pi \Delta V\right]}{\Delta \pi \Delta V\left[\pi_{1} \bar{V}+\left(1-\pi_{1}\right) \underline{V}\right]}+\frac{f}{\pi_{1} \bar{V}+\left(1-\pi_{1}\right) \underline{V}}$, then it is optimal for the owner to choose the professional governance; if $s<1+\lambda+\frac{\Psi\left[\pi_{1} \bar{V}+\left(1-\pi_{1}\right) \underline{V}-\Delta \pi \Delta V\right]}{\Delta \pi \Delta V\left[\pi_{1} \bar{V}+\left(1-\pi_{1}\right) \underline{V}\right]}+\frac{f}{\pi_{1} \bar{V}+\left(1-\pi_{1}\right) \underline{V}}$, then it is optimal for the owner to choose the relational governance.

Proof: When $\Psi<\frac{\Psi_{0}^{R}\left[\pi_{1} \bar{V}+\left(1-\pi_{1}\right) \underline{V}\right]}{\left[\pi_{1} \bar{V}+\left(1-\pi_{1}\right) \underline{V}\right]-\Delta \pi \Delta V}$, if

$s \geq 1+\lambda+\frac{\Psi\left[\pi_{1} \bar{V}+\left(1-\pi_{1}\right) \underline{V}-\Delta \pi \Delta V\right]}{\Delta \pi \Delta V\left[\pi_{1} \bar{V}+\left(1-\pi_{1}\right) \underline{V}\right]}+\frac{f}{\pi_{1} \bar{V}+\left(1-\pi_{1}\right) \underline{V}}$, then from (6) and (10),

we obtain: $U_{O}^{R^{*}}-U_{O}^{P^{*}} \leq 0$.

When $\Psi<\frac{\Psi_{0}^{R}\left[\pi_{1} \bar{V}+\left(1-\pi_{1}\right) \underline{V}\right]}{\left[\pi_{1} \bar{V}+\left(1-\pi_{1}\right) \underline{V}\right]-\Delta \pi \Delta V}$, if

$s<1+\lambda+\frac{\Psi\left[\pi_{1} \bar{V}+\left(1-\pi_{1}\right) \underline{V}-\Delta \pi \Delta V\right]}{\Delta \pi \Delta V\left[\pi_{1} \bar{V}+\left(1-\pi_{1}\right) \underline{V}\right]}+\frac{f}{\pi_{1} \bar{V}+\left(1-\pi_{1}\right) \underline{V}}$, then from (6) and (10),

we obtain: $U_{O}^{R^{*}}-U_{O}^{P^{*}}>0$.

From Proposition 4, we know that when the exertion cost is sufficiently small relative to the uneasiness cost, if the professional manager's ability is big enough relative to the relational manager's degree of altruism and the owner's clan rent, then the owner tends to choose the professional governance; however, if the professional manager's ability is small enough relative to the relational manager's degree of altruism and the owner's clan rent, then the owner tends to choose the relational governance. 


\section{Results and discussion}

In this section, we will discuss the main results obtained in Subsection 3.4 in order to understand them more deeply and illustrate them more graphically. Our discussion could illustrate the meaning behind our main conclusion that the choice of governance modes is condition-dependent more clearly.

If we let $\Psi^{+}$denote $\Psi \geq \frac{\Psi_{0}^{R}\left[\pi_{1} \bar{V}+\left(1-\pi_{1}\right) \underline{V}\right]}{\left[\pi_{1} \bar{V}+\left(1-\pi_{1}\right) \underline{V}\right]-\Delta \pi \Delta V}, \Psi^{-}$represent

$\Psi<\frac{\Psi_{0}^{R}\left[\pi_{1} \bar{V}+\left(1-\pi_{1}\right) \underline{V}\right]}{\left[\pi_{1} \bar{V}+\left(1-\pi_{1}\right) \underline{V}\right]-\Delta \pi \Delta V}, s_{1}^{+}$stand for $s \geq 1+\lambda+\frac{\Psi_{0}^{R}}{\Delta \pi \Delta V}+\frac{f}{\pi_{1} \bar{V}+\left(1-\pi_{1}\right) \underline{V}}$,

$s_{1}^{-}$denote $s<1+\lambda+\frac{\Psi_{0}^{R}}{\Delta \pi \Delta V}+\frac{f}{\pi_{1} \bar{V}+\left(1-\pi_{1}\right) \underline{V}}, s_{2}^{+}$stand for

$s \geq 1+\lambda+\frac{\Psi\left[\pi_{1} \bar{V}+\left(1-\pi_{1}\right) \underline{V}-\Delta \pi \Delta V\right]}{\Delta \pi \Delta V\left[\pi_{1} \bar{V}+\left(1-\pi_{1}\right) \underline{V}\right]}+\frac{f}{\pi_{1} \bar{V}+\left(1-\pi_{1}\right) \underline{V}}, s_{2}^{-}$denote

$s<1+\lambda+\frac{\Psi\left[\pi_{1} \bar{V}+\left(1-\pi_{1}\right) \underline{V}-\Delta \pi \Delta V\right]}{\Delta \pi \Delta V\left[\pi_{1} \bar{V}+\left(1-\pi_{1}\right) \underline{V}\right]}+\frac{f}{\pi_{1} \bar{V}+\left(1-\pi_{1}\right) \underline{V}}$, then Propositions 3-4 can

be summarized by Table 1 .

Table 1: The owner's condition-dependent choice of governance modes

\begin{tabular}{|c|c|c|}
\hline Governance mode & Relational governance & Professional governance \\
\hline \multirow{2}{*}{ Condition } & $\Psi^{+}$and $s_{1}^{-}$ & $\Psi^{+}$and $s_{1}^{+}$ \\
\cline { 2 - 3 } & $\Psi^{-}$and $s_{2}^{-}$ & $\Psi^{-}$and $s_{2}^{+}$ \\
\hline
\end{tabular}

Source: Author's calculations

From Table 1, it is easy for us to find that the comparison between the manager's exertion cost and uneasiness cost plays a first-order role, and that the comparison between the professional manager's ability and the relational manager's degree of altruism and the owner's clan rent plays a second-order role. That is to say, there is a subtle and dilemmatic contrast between reducing the professional manager's moral hazard and enhancing the relational manager's ability.

In order to enunciate more clearly, Table 1 can also be depicted by Figure 3. 
Figure 3: The owner's choice of governance modes

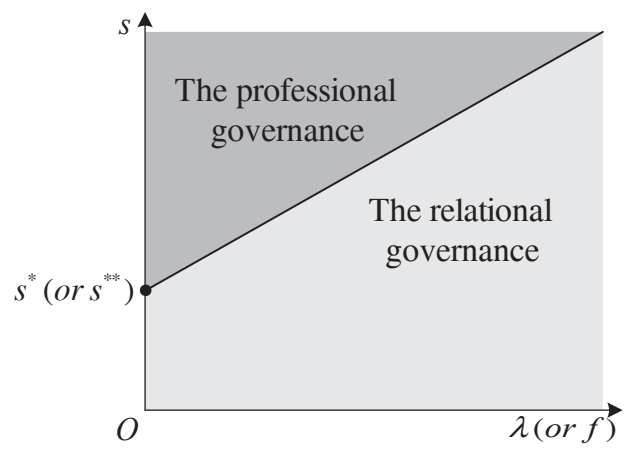

Source: Author's calculations

According to above analyses, we can find the following: (i) as for the plane of

$s$ and $\lambda, s^{*}=1+\frac{\Psi_{0}^{R}}{\Delta \pi \Delta V}+\frac{f}{\pi_{1} \bar{V}+\left(1-\pi_{1}\right) \underline{V}}$ or

$s^{* * * *}=1+\frac{\Psi\left[\pi_{1} \bar{V}+\left(1-\pi_{1}\right) \underline{V}-\Delta \pi \Delta V\right]}{\Delta \pi \Delta V\left[\pi_{1} \bar{V}+\left(1-\pi_{1}\right) \underline{V}\right]}+\frac{f}{\pi_{1} \bar{V}+\left(1-\pi_{1}\right) \underline{V}} ;$ and (ii) as for the plane of $s$

and $f, s^{*}=1+\lambda+\frac{\Psi_{0}^{R}}{\Delta \pi \Delta V}$ or $\quad s^{* *}=1+\lambda+\frac{\Psi\left[\pi_{1} \bar{V}+\left(1-\pi_{1}\right) \underline{V}-\Delta \pi \Delta V\right]}{\Delta \pi \Delta V\left[\pi_{1} \bar{V}+\left(1-\pi_{1}\right) \underline{V}\right]}$.

No matter which plane is focused on by us, the black line in Figure 3 is

$s=1+\lambda+\frac{\Psi_{0}^{R}}{\Delta \pi \Delta V}+\frac{f}{\pi_{1} \bar{V}+\left(1-\pi_{1}\right) \underline{V}}$ or

$s=1+\lambda+\frac{\Psi\left[\pi_{1} \bar{V}+\left(1-\pi_{1}\right) \underline{V}-\Delta \pi \Delta V\right]}{\Delta \pi \Delta V\left[\pi_{1} \bar{V}+\left(1-\pi_{1}\right) \underline{V}\right]}+\frac{f}{\pi_{1} \bar{V}+\left(1-\pi_{1}\right) \underline{V}}$.

Thus, above the black line, the owner had better choose the professional governance; and below the black line, the owner had better adopt the relational governance. Figure 3 can give us a better intuition of the basic tradeoffs and the internal mechanisms in this paper.

\section{Conclusions}

In this paper, we mainly discuss the choice of governance modes in Chinese family firms. There are two modes of governance that the owner of the family firm can choose from, either the relational governance or the professional governance. 
The choice of governance modes is embodied in managerial compensation under different contractual arrangements. Our hypotheses have been proved by our theoretical analyses. We find that under some conditions it is optimal for the owner to choose the relational governance, while under other conditions it is optimal for the owner to adopt the professional governance. In a word, the choice of governance modes is condition-dependent. Under the relational governance, the owner appoints the manager by favoritism, which is called "renrenweiqin" in Chinese language. Under the professional governance, the owner appoints the manager according to his ability, which is called "renrenweixian" in Chinese language. According to Propositions 3-4, Table 1 and Figure 3, it is obvious that the owner has to make a tradeoff on the choice of governance modes. As we know, the relational manager is with lower degree of moral hazard and lower level of ability, while the professional manager is with higher degree of moral hazard and higher level of ability. A Chinese proverb says, "Where there is a gain, there is a loss." That is to say, the choice of governance modes is determined by the joint roles of many influencing factors that are mentioned by Figure 2. Here, we point out the matters needing attention of our main results. Firstly, although most people in China hold that Chinese family firms should adopt the professional governance in order to go with the tide of economic development, we find that the relational governance may be a better choice under some conditions. Secondly, different owners of Chinese family firms may put different weights on their clan rents and the relational managers' degree of altruism, and this will affect the basic tradeoffs and the eventual choice of governance modes. That is to say, the owners' role of subjective intentions cannot be neglected. However, many people unwittingly ignore such a role. Thirdly, the tradeoff between one agent's loyalty (i.e., altruism in this paper's sense) and another agent's ability is not only a problem existing in Chinese family firms, but also a problem prevalent in some governments. Put differently, such a tradeoff is important in many fields. In the end, according to Cheng's (2014, p.149) important literature review, "We call for more research to understand the unique family effects and encourage more research on Chinese family firms." This paper just throws away a brick in order to get a gem.

\section{References}

Amit, R., Ding, Y., Villalonga, B., Zhang, H. (2015) “The Role of Institutional Development in the Prevalence and Performance of Entrepreneur and FamilyControlled Firms", Journal of Corporate Finance, Vol. 31, pp. 284-305, doi: 10.1016/j.jcorpfin.2015.01.001.

Bebchuk, L. A., Fried, J. (2003) "Executive Compensation as an Agency Problem", Journal of Economic Perspectives, Vol. 17, No. 3, pp. 71-92, doi: 10.1257/089533003769204362. 
Bebchuk, L. A., Weisbach, M. S. (2010) "The State of Corporate Governance Research", Review of Financial Studies, Vol. 23, No. 2, pp. 939-961, doi: 1093/ $\mathrm{rfs} / \mathrm{hhp} 121$.

Becker, G. S. (1976) "Altruism, Egoism, and Genetic Fitness: Economics and Sociobiology", Journal of Economic Literature, Vol. 14, No. 3, pp. 817-826.

Bi, Y. (2010) Research on Exchanging Governance Model in Family Firms (in Chinese), Chengdu: Southwestern University of Finance and Economics Press.

Burkart, M., Panunzi, F., Shleifer, A. (2003) "Family Firms", Journal of Finance, Vol. 58, No. 5, pp. 2167-2201, doi: 10.1111/1540-6261.00601.

Cai, H., Li, H., Park, A., Zhou, L.-A. (2013) "Family Ties and Organizational Design: Evidence from Chinese Private Firms", Review of Economics and Statistics, Vol. 95, No. 3, pp. 850-867, doi: 10.1162/rest_a_00268.

Carney, M. (1998) "A Management Capacity Constraint? Obstacles to the Development of the Overseas Chinese Family Business", Asia Pacific Journal of Management, Vol. 15, No. 2, pp. 137-162, doi: 10.1023/a:1015433429765.

Cheng, Q. (2014) "Family Firm Research-A Review", China Journal of Accounting Research, Vol. 7, No. 3, pp. 149-163, doi: 10.2139/ssrn.2391575.

Coase, R., Wang, N. (2010) "Ten Directions for Chinese Economy Research", China Reform (Zhongguo Gaige), No. 3, pp. 86-89.

Dekker, J., Lybaert, N., Steijvers, T., Depaire, B. (2015) "The Effect of Family Business Professionalization as a Multidimensional Construct on Firm Performance", Journal of Small Business Management, Vol. 53, No. 2, pp. 516538, doi: $10.1111 /$ jsbm. 12082.

Dou, J., Li, S. (2013) "The Succession Process in Chinese Family Firms: A Guanxi Perspective", Asia Pacific Journal of Management, Vol. 30, No. 3, pp. 893-917, DOI: $10.1007 / \mathrm{s} 10490-012-9287-7$.

Dou, J., Zhang, Z., and Su, E. (2014) "Does Family Involvement Make Firms Donate More? Empirical Evidence from Chinese Private Firms", Family Business Review, Vol. 27, No. 3, pp. 259-274, doi: 10.1177/0894486514538449.

Holmstrom, B. (1979) "Moral Hazard and Observability", Bell Journal of Economics, Vol. 10, No. 1, pp. 74-91, doi: 10.2307/3003320.

Itoh, H. (2004) "Moral Hazard and Other-Regarding Preferences", Japanese Economic Review, Vol. 55, No. 1, pp. 18-45, doi: 10.2139/ssrn.454500.

Kim, Y., Gao, F. Y. (2013) "Does Family Involvement Increase Business Performance? Family-longevity Goals' Moderating Role in Chinese Family Firms", Journal of Business Research, Vol. 66, No. 2, pp. 265-274, doi: 10.1016/j.jbusres.2012.08.018.

Laffont, J.-J., Martimort, D. (2002) The Theory of Incentives, New Jersey: Princeton University Press. 
Liang, X., Wang, L., Cui, Z. (2014) "Chinese Private Firms and Internationalization: Effects of Family Involvement in Management and Family Ownership", Family Business Review, Vol. 27, No. 2, pp. 126-141, doi: 10.1177/0894486513480885.

Milana, C., Wang, J. (2013) "Fostering Entrepreneurship in China: A Survey of the Economic Literature", Strategic Change, Vol. 22, Nos. 7-8, pp. 387-415, doi: $10.1002 /$ jsc. 1947.

Pi, J. (2011a) "The Choice between the Formal and Relational Financing in Chinese Family Firms", Economic Computation and Economic Cybernetics Studies and Research, Vol. 45, No. 1, pp. 189-201.

Pi, J. (2011b) "Relational Incentives in Chinese Family Firms", Panoeconomicus, Vol. 58, No. 4, pp. 511-524, doi: 10.2298/PAN1104511P.

Xie, H. (2011) The Governance of Family and Family Firms: The Integration of Relational Contracts and Corporation Rules (in Chinese), Hangzhou: Zhejiang University Press.

Yang, G. (2009) Guanxi Governance in Chinese Business and Its Evolution: Taking Zhejiang Yixing Group as a Case (in Chinese), Beijing: Social Sciences Academic Press.

Zhang, J., Ma, H. (2009) “Adoption of Professional Management in Chinese Family Business: A Multilevel Analysis of Impetuses and Impediments", Asia Pacific Journal of Management, Vol. 26, No. 1, pp. 119-139, doi: 10.1007/s10490-0089099-y.

Zhou, J., Tam O. K., Lan, W. (2015) "Are Investor Protection and Ownership Concentration Substitutes in Chinese Family Firms?", Emerging Markets Finance and Trade, Vol. 51, No. 2, pp. 432-443, doi: 10.1080/1540496X.2015.1024553.

Zhou, J., Tam O. K., Yu, P. (2013) "An Investigation of the Role of Family Ownership, Control and Management in Listed Chinese Family Firms", Asian Business \& Management, Vol. 12, No. 2, pp. 197-225, doi: 10.1057/ abm.2012.40. 
Istraživanje o izboru načina upravljanja u kineskim obiteljskim tvrtkama ${ }^{1}$

$$
\text { Jiancai } P i^{2}
$$

\begin{abstract}
Sažetak
Ovaj rad ima za cilj istražiti izbor načina upravljanja u kineskim obiteljskim tvrtkama. U tu svrhu primijenjen je model nalogodavca -zastupnika za provođenje analize. Postoje dva načina upravljanja koji vlasnik obiteljske tvrtke može odabrati, relacijsko upravljanje ili profesionalno upravljanje. Izbor načina upravljanja temelji se na menadžerskoj kompenzaciji pod različitim ugovornim uvjetima. Naše teorijske analize pokazuju da je u nekim uvjetima optimalno da se vlasnik opredjeljuje za relacijsko upravljanje, dok pod drugim uvjetima, optimalan izbor je profesionalno upravljanje. Naime, izbor načina upravljanja ovisi o uvjetima.
\end{abstract}

Ključne riječi: relacijsko upravljanje, profesionalno upravljanje, kineska obiteljska tvrtka, moralna opasnost

JEL klasifikacija: L20, M21, J33

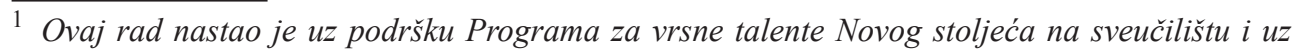
potporu zaklade za temeljna istraživanja središnjih sveučilišta (Program for New Century Excellent Talents in University and the Fundamental Research Funds for the Central Universities). Autor se također želi zahvaliti uredniku i anonimnim recenzentima za njihovu iskrenu pomoć i preporukama koje su doprinijele kvaliteti ovog rada.

2 Redoviti profesor, Department of Economics, School of Business, Nanjing University, 22 Hankou Road, Nanjing 210093, Kina. Znanstveni interes: organizacijska ekonomija, ekonomika razvoja.Tel.:+862583621121(O).E-mail:pi2008@nju.edu.cn; jiancaipi@hotmail.com.Web stranica: http://nubs.nju.edu.cn/en/faculty.php/160; http://nubs.nju.edu.cn/faculty.php/160. 
